\title{
Exploring Comparative Ridership Drivers of Bus Rapid Transit and Light Rail Transit Routes
}

\author{
Graham Currie and Alexa Delbosc \\ Monash University
}

\begin{abstract}
A major research gap is the relative ridership performance of Bus Rapid Transit (BRT), Light Rail Transit (LRT), and streetcar (SC). This paper assesses ridership influences of 101 routes in Australia, Europe, and North America using multiple regression examining the influence of transit mode, vehicle capacity, service level, employment/residential density, car ownership, speed, stop spacing, right-of-way, vehicle accessibility, and integrated fares on ridership (boardings/vehicle km; BVK). Average ridership is higher for LRT/SC routes than for BRT routes, and although service levels vary greatly, they are lower on BRT systems. Residential/employment density is higher for $L R T / S C$ routes compared to BRT. A regression model predicting BVK was significant $\left(R_{2}=0.83\right)$ with six predictors: being in Europe, speed, vehicle capacity, employment density, service level, and integrated ticketing. Results suggest that the transit mode does not directly impact ridership but rather acts through vehicle size and service levels. Limitations and opportunities for future research are identified.
\end{abstract}

\section{Introduction}

Cities facing the challenge of expanding transit often find themselves weighing the relative costs and merits of Bus Rapid Transit (BRT) versus Light Rail Transit (LRT). However, a major research gap is empirical assessment of the comparative merits of BRT versus LRT. Although the relative costs of LRT and BRT have been analyzed 
(U.S. General Accounting Office 2001; UK Commission for Integrated Transport 2005), there is almost no research that explores relative ridership impacts of one mode over the other.

This paper presents the findings of an empirical route level analysis of the factors influencing ridership on a series of BRT, LRT, and streetcar (SC) routes in Australia, Europe, and North America. Its aim is to provide an objective base to determine whether the transit mode has a significant influence on ridership above and beyond the influence of other important variables such as service level or urban density. The research integrates the data sets from two separate studies predicting the ridership of BRT systems in Australia (Currie and Delbosc 2011) and LRT/ SC ridership in Australia, Europe, and North America (Currie, Ahern, and Delbosc 2011). The analysis will help inform cities that are comparing the relative merits of a BRT or LRT system for their needs.

The paper is structured as follows. The first section overviews previous research associated with route-level ridership drivers. This is followed by a discussion of the methodology used to collate and analyze the data. Results are then presented, followed by conclusions from the research.

\section{Previous Research}

A summary of previous research on factors that influence LRT and BRT ridership is presented in Table 1.

High service levels, measured in terms of frequency and span of hours covered, has often been cited as an important driver of patronage on all public transport modes. Urban density is also identified as an important influence: "Nearly every study that has focused on transit ridership has provided evidence that density is the primary determinant of transit ridership" (Johnson 2003, 32). Much research cites the importance of an integrated public transport network as a key driver of high light rail patronage (FitzRoy and Smith 1998; Denant Boemont and Mills 1999; Babalik-Sutcliffe 2002) and transit patronage in general (Nielsen et al. 2005). Patronage drivers in this case involve service and fare integration as well as the wider "network effects" these can generate. A range of other factors has been suggested that might also influence light rail ridership. Cheap fares were cited in two reports (FitzRoy and Smith 1998; Kain and Liu 1999). A number of researchers cite the importance of a strong policy context as a basis for high light rail ridership (e.g., Knowles 2007). Several researchers have suggested that high car ownership can 
reduce light rail usage (Mackett and Babalik-Sutcliffe 2003; Babalik-Sutcliffe 2002). Hass-Klau and Crampton (2002) suggested that pedestrian zone length in cities, average speed, stop distance, and the density of the light rail network were also related to their index of light rail performance (based on ridership per route $\mathrm{km}$ ). Correlation analysis suggested better performance (ridership) at slower speeds and short stop distances (Crampton 2002). This counter-intuitive result is because LRT systems tend to have higher ridership in inner city areas where speeds and stop spacing are lower/shorter (an outcome of higher ridership rather than a driver).

Table 1. Ridership Drivers Identified in Previous Research

\begin{tabular}{|l|l|}
\hline Identified Driver & Resource Source \\
\hline High Service Levels & $\begin{array}{l}\text { FitzRoy and Smith 1998; Kain and Liu 1999; Currie and Wallis } \\
\text { 2008; Stopher 1992; Mackett and Babalik-Sutcliffe 2003; Hen- } \\
\text { sher and Golob 2008 }\end{array}$ \\
\hline $\begin{array}{l}\text { High-Density Residential } \\
\text { Development }\end{array}$ & $\begin{array}{l}\text { Johnson 2003; Babalik-Sutcliffe 2002; Kain and Liu 1999; Kain, } \\
\text { Barranda, and Upchurch 2004; Seskin and Cervero 1996 }\end{array}$ \\
\hline $\begin{array}{l}\text { Modal Integration and } \\
\text { Network Effect }\end{array}$ & $\begin{array}{l}\text { Mackett and Babalik-Sutcliffe 2003; Kain, Barranda, and Up- } \\
\text { church 2004; Babalik-Sutcliffe 2002; Denant Boemont and Mills } \\
\text { 1999 }\end{array}$ \\
\hline Ticket Integration & $\begin{array}{l}\text { Crampton 2002; Hass-Klau and Crampton 2002; Mackett and } \\
\text { Babalik-Sutcliffe 2003 }\end{array}$ \\
\hline Low Car Ownership & Mackett and Babalik-Sutcliffe 2003; Babalik-Sutcliffe 2002 \\
\hline Low Fares & $\begin{array}{l}\text { Mackett and Babalik-Sutcliffe 2003; Kain and Liu 1999; Hensher } \\
\text { and Golob 2008 }\end{array}$ \\
\hline High Speed & Hass-Klau and Crampton 2002; Crampton 2002 \\
\hline Stop Distance & Hass-Klau and Crampton 2002; Crampton 2002 \\
\hline Light Rail Network Density & Hass-Klau and Crampton 2002; Crampton 2002 \\
\hline Reliable Service & Mackett and Babalik-Sutcliffe 2003 \\
\hline Pedestrianization & Hass-Klau and Crampton 2002 \\
\hline Strong Economic Conditions & Babalik-Sutcliffe 2002 \\
\hline High Employment & Kain and Liu 1999 \\
\hline Strong Policy Support & Knowles 2007 \\
\hline Easy Station Access & Kain and Liu 1999 \\
\hline Number of Stations & Hensher and Golob 2008 \\
\hline & \\
\hline
\end{tabular}


The results of two sets of empirical studies are worthy of closer attention. The first (Hass-Klau and Crampton 2002; Crampton 2002) concern system-wide (rather than route-level) data from 24 light rail systems (75\% from Europe). The authors report that major explanatory variables include travel card use (ticket integration), CBD pedestrianization, population density, and low fares. The second noteworthy empirical source examines BRT system performance (Hensher and Golob 2008). This involved a comparative assessment of system-wide data from 44 worldwide BRT systems. The authors found that more stations and higher service levels (measured as headway and capacity) increased ridership, whereas higher fares were negatively correlated with ridership.

Overall, empirical research has uncovered many factors that influence LRT or BRT ridership; however, results vary between studies and also by context. None consider the relative influences for BRT or LRT systems within the same analysis. There is clearly room for research to explore ridership drivers between BRT and LRT in a more consistent manner.

\section{Research Approach and Methodology}

Route-level data for 44 BRT routes and 57 LRT lines were collated (Table 2). Railbased routes were further subdivided into light rail transit (LRT) and streetcar (SC) routes to further explore the nature of these modes (defined as light rail if over $50 \%$ of the route had segregated right of way). Every SC/LRT in Australia was included. Light rail routes in North America and Europe were chosen based on the availability of reliable data at the route level. Further details about collecting these data are available (see Appendix A, Currie, Ahern, and Delbosc 2011; Currie and Delbosc 2011).

Due to limitations in available data, only Australian BRT data could be included in this analysis. Although this is an acknowledged limitation of the data, Australian BRT includes a wide range of service characteristics. The key features that distinguish BRT from traditional route buses include a mix of runningways, quality stations and vehicles, intelligent transport systems, and high-frequency service patterns (Levinson et al. 2003). Australian systems vary from major commuter busways with grade-separated corridors (Brisbane and Adelaide) to dedicated bus lanes (Sydney) to primarily on-street "BRT light" (Melbourne) (Currie and Delbosc 2010). 
Table 2. Route Services Selected For Analysis

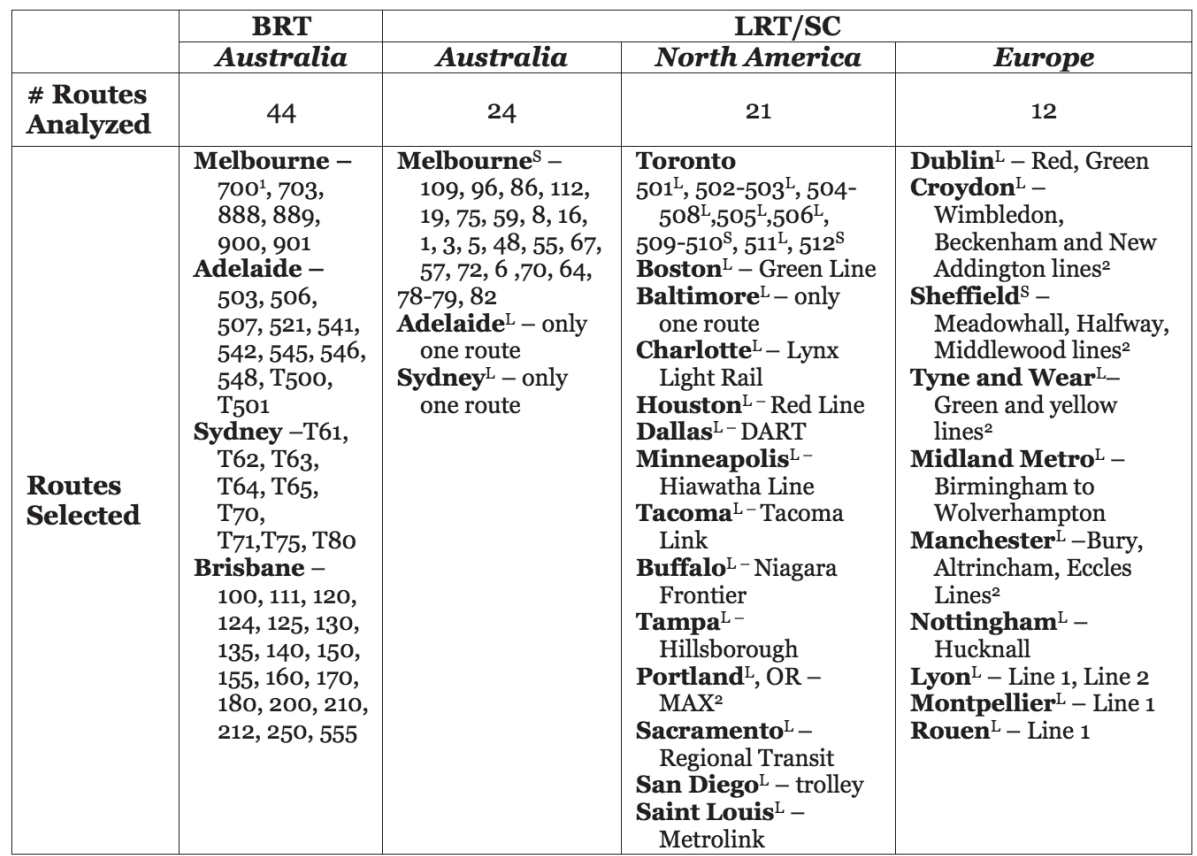

${ }^{1}$ In 2008, this was route 700, and it has since been re-branded the 903 SmartBus route. For the purpose of this analysis, it was included as a SmartBus service.

${ }^{2}$ These lines analyzed as a group due to poor data availability.

LLight rail.

sStreetcar.

Analysis included simple comparative analysis, correlations and linear regression modeling.

Boardings per vehicle kilometer (BVK) was the dependent variable selected for analysis in the regression modeling. BVK enables ridership to be examined relative to the level of service ( $\mathrm{vkms}$ ) operated, controlling for the strong influence of service levels on ridership found in previous research (e.g., Stopher 1992; Currie and Wallis 2008). ${ }^{1}$ Explanatory variables were selected based on those used in previous research (Table 1), and available data and are detailed in Table 3. Data were not all available for the same year and ranged from between 2001 and 2009. 


\section{Table 3. Explanatory Data Collected}

\begin{tabular}{|c|c|}
\hline Data & Derivation \\
\hline Service Level & $\begin{array}{l}\text { Vehicle trips per annum was adopted and calculated by dividing the annual } \\
\text { vehicle kilometers by route length in one direction. This is a broad indicator of } \\
\text { service levels, encompassing service frequency, service span, and coverage of } \\
\text { nights and weekend services. Unlike vehicle kilometers, this measure controls } \\
\text { for route length. }\end{array}$ \\
\hline $\begin{array}{l}\text { Vehicle } \\
\text { Capacity }\end{array}$ & $\begin{array}{l}\text { Vehicle capacity was classified into one of five categories: } 100 \text { or less, 101-150, } \\
151-200,201-250 \text { and } 250+\text {. Non-crush standing and sitting capacity was } \\
\text { used. }\end{array}$ \\
\hline $\begin{array}{l}\text { Employment } \\
\text { \& Residential } \\
\text { Density }\end{array}$ & $\begin{array}{l}\text { Residential density and employment density (expressed in residents or jobs } \\
\text { per square km) were calculated within an } 800 \mathrm{~m} \text { catchment of the route align- } \\
\text { ment using mainly GIS analysis where available. Some North American and } \\
\text { European routes had to be calculated based on city-wide data. }\end{array}$ \\
\hline Car Ownership & $\begin{array}{l}\text { This is expressed as cars per } 1,000 \text { people and was calculated for residents } \\
\text { within } 800 \mathrm{~m} \text { of route alignment using GIS analysis where available. Some } \\
\text { North American and European routes had to be calculated based on city- } \\
\text { wide data. }\end{array}$ \\
\hline Average Speed & $\begin{array}{l}\text { In some cases, this was provided by operators or other sources (see Appendix } \\
\text { A). When not directly available, average speed was calculated by dividing } \\
\text { route length by run time. Run time was taken at the } 8 \mathrm{AM} \text { peak. Values are } \\
\text { expressed as km per hour. }\end{array}$ \\
\hline Stop Spacing & $\begin{array}{l}\text { Calculated by dividing route length by number of stops minus one. This was } \\
\text { calculated using each stop, not just timing stops. Values are expressed in } \\
\text { meters. }\end{array}$ \\
\hline $\begin{array}{l}\text { Separate } \\
\text { Right-of-Way } \\
\text { Share }\end{array}$ & $\begin{array}{l}\text { Right-of-way was defined as the share of route separate from mixed traffic. } \\
\text { This includes both ROW-A (fully grade-separated) and ROW-B (cross-traffic at } \\
\text { intersections). }\end{array}$ \\
\hline $\begin{array}{l}\text { Vehicle } \\
\text { Accessibility }\end{array}$ & $\begin{array}{l}\text { For BRT routes, defined as the proportion of buses on a route that were } \\
\text { low-floor or otherwise wheelchair-accessible (for Brisbane, this had to be } \\
\text { estimated as a proportion of total fleet, e.g., all routes were assigned the } \\
\text { same accessibility level). For LRT, defined as the proportion of stops that were } \\
\text { wheelchair-accessible. }\end{array}$ \\
\hline $\begin{array}{l}\text { Integrated } \\
\text { Fares }\end{array}$ & $\begin{array}{l}\text { Routes were classified as having "fully integrated ticketing" if passengers were } \\
\text { able to transfer between modes without having to buy a separate ticket. }\end{array}$ \\
\hline Region & $\begin{array}{l}\text { Regions may have further intangible differences in culture and expectations. } \\
\text { For this reason, dummy variables accounting for Europe, North America, and } \\
\text { Australia were included. }\end{array}$ \\
\hline Mode & $\begin{array}{l}\text { A major research aim is to determine if mode (BRT, LRT, or SC) has a signifi- } \\
\text { cant influence on ridership above and beyond the influence of other variables. }\end{array}$ \\
\hline
\end{tabular}




\section{Regression Methodology}

A linear regression modeling approach was adopted using the following model:

$$
Y_{i}=\beta_{0}+\beta_{1} X_{i 1}+\beta_{2} X_{i 2}+\cdots+\beta_{n} X_{i n}+\varepsilon_{i}
$$

Where:

$$
\begin{aligned}
& Y_{i}=\text { Dependent variable } i \\
& X_{i}=\text { Independent variables predicting } Y_{i} \\
& \beta=\text { Regression coefficients to be estimated } \\
& \varepsilon=\text { Error }
\end{aligned}
$$

Step-wise regression was used to test the relationships between ridership (BVK) and the explanatory variables measured for each route. Explanatory variables were included in the model based on their level of statistical significance (a significance probability of $95 \%$ was adopted for inclusion, and removal was based on a significance threshold of below 90\%). A number of statistical tests were undertaken to assess the reliability of the analysis. Mahalanobis distances (distance of cases from the mean of the predictor variables [Barnett and Lewis 1978]) and leverage values (also called hat values, which gauge the influence of the observed value of the outcome variable over the predicted values [Stevens 2002]) determine whether a single case is having an undue influence on the significance of the model. Collinearity tests whether predictors in the model are so highly correlated as to be interchangeable (Myers 1990).

Explanatory variables were those identified in Table 3. Mode, continent, and integrated ticketing were coded using dummy variables. Capacity was encoded as a five-category variable.

\section{Analysis}

\section{Summary Statistics}

Table 4 shows summary statistics from the routes analyzed by mode and continent. Average route ridership (BVK) is higher for LRT (6.7) than SC (6.5) and is considerably higher than for BRT (1.3). Service levels vary greatly between mode and regions. Vehicle trips per annum are 4.2 times higher on LRT than BRT and 3 times higher on SC. Vehicle trips are highest in North American LRT, which has higher service but considerably lower ridership than European LRT. 
Table 4. Average Route-Level Statistics By Mode And Continent

\begin{tabular}{|c|c|c|c|c|c|c|c|}
\hline & & BRT & & LRT/SC & & & \\
\hline & & Australia & Australia & $\begin{array}{c}\mathrm{N} . \\
\text { America }\end{array}$ & Europe & Total & Total \\
\hline Dependent Vari & les (Ridersh & & & & & & \\
\hline Boardings/ & Mean & 1.3 & 6.4 & 5.2 & 9.5 & 6.7 & 6.5 \\
\hline Veh Km BVK) & SD & 0.4 & 2.0 & 2.3 & 3.8 & 3.9 & 1.8 \\
\hline Explanatory Var & ples & & & & & & \\
\hline Service Level & Mean & 23,784 & 64,260 & 114,877 & 94,679 & 100,501 & 72,334 \\
\hline annum) & SD & 16,974 & 15,341 & 58,811 & 18,208 & 46,935 & 30,979 \\
\hline Residential & Mean & 1,848 & 3,713 & 3,222 & 2,484 & 1,855 & 4,642 \\
\hline Density & SD & 303 & 942 & 3,948 & 1,439 & 2,218 & 2,100 \\
\hline Employment & Mean & 3,266 & 7,611 & 2,500 & 1,506 & 1,906 & 6,892 \\
\hline Density & SD & 1,701 & 2,455 & 3,296 & 1,098 & 3,174 & 2,440 \\
\hline Car Ownership & Mean & 529 & 434 & 531 & 396 & 514 & 412 \\
\hline & SD & 33 & 53 & 156 & 78 & 143 & 56 \\
\hline Average Speed & Mean & 26 & 17 & 18 & 25 & 21 & 17 \\
\hline$(\mathrm{kph})$ & SD & 6 & 2 & 7 & 6 & 7 & 3 \\
\hline Stop Spacing & Mean & 1,068 & 279 & 841 & 722 & 908 & 262 \\
\hline & SD & 589 & 98 & 642 & 251 & 505 & 81 \\
\hline$\%$ Accessible & Mean & $62 \%$ & $21 \%$ & $54 \%$ & $100 \%$ & $87 \%$ & $14 \%$ \\
\hline & SD & $21 \%$ & $26 \%$ & $50 \%$ & $0 \%$ & $33 \%$ & $19 \%$ \\
\hline$\%$ Segregated & Mean & $41 \%$ & $24 \%$ & $70 \%$ & $87 \%$ & $94 \%$ & $15 \%$ \\
\hline Right-of-Way & SD & $29 \%$ & $23 \%$ & $46 \%$ & $19 \%$ & $10 \%$ & $15 \%$ \\
\hline Integrated Fares & Percent & $80 \%$ & $96 \%$ & $76 \%$ & $50 \%$ & $61 \%$ & $97 \%$ \\
\hline Capacity & 100 or less & $75 \%$ & $0 \%$ & $5 \%$ & $0 \%$ & $4 \%$ & $0 \%$ \\
\hline (category) & $101-150$ & $25 \%$ & $63 \%$ & $5 \%$ & $0 \%$ & $7 \%$ & $48 \%$ \\
\hline & $151-200$ & $0 \%$ & $29 \%$ & $52 \%$ & $17 \%$ & $32 \%$ & $38 \%$ \\
\hline & $201-250$ & $0 \%$ & $4 \%$ & $29 \%$ & $50 \%$ & $36 \%$ & $10 \%$ \\
\hline & $250+$ & $0 \%$ & $4 \%$ & $10 \%$ & $33 \%$ & $21 \%$ & $3 \%$ \\
\hline
\end{tabular}

Residential density tends to be higher for LRT/SC compared to BRT. This may be due to inner-city concentration, whereas many of the Australian BRT systems extend to the suburbs. Employment density is highest amongst Australian LRT/ SC systems for similar reasons. Interestingly, European residential and employment 
densities are relatively low, which is consistent with previous research (Hass-Klau and Crampton 2002).

Car ownership is lowest amongst European LRT routes. The car ownership in American LRT cities is nearly identical to that in Australian BRT systems, but higher than Australian LRT/SC systems. This, again, is a reflection of the inner urban concentration of Australian LRT/SC.

BRT systems tend to have smaller vehicles, although Brisbane uses articulated vehicles that placed their capacity into the second category. European LRT/SC systems employ the largest vehicles, with 83 percent with a capacity of more than 200. North American systems tend to use mid-sized vehicles, followed by Australian LRT/SC.

Australian BRT routes are characterized by fast run speeds (higher than LRT/SC), larger stop spacing, relatively accessible buses, mostly integrated fares, and some segregated right of way.

There are major differences between LRT/SC routes in different regions. Australia is dominated by Melbourne's SC routes, which reflect in the slowest running speeds, smaller vehicles, and smallest average stop distance of only $279 \mathrm{~m}$. Only a small proportion of the routes have segregated right-of-way, and the vehicles are unlikely to be accessible. However, they are the most likely routes to have integrated ticketing systems. European systems are dominated by high-capacity LRT rather than SC and have high running speeds and high ROW share, all vehicles are considered accessible, and half the ticketing systems are integrated. North American routes have long stop distances but mid-sized vehicles and only moderate run speeds despite being dominated by LRT systems with high separate ROW share.

\section{Initial Correlations}

Initial analysis explored links between ridership and service levels because previous research suggested strong influences (FitzRoy and Smith 1998; Currie, Ahern, and Delbosc 2011; Stopher 1992; Currie and Wallis 2008; Mackett and Babalik-Sutcliffe 2003; Kain and Liu 1999). Figure 1 graphs each route based on BVK and transit vehicle trips per annum (a measure of service frequency/level). A strong relationship between the two is apparent: routes with low vehicle trips tend to have lower ridership (correlation $r=0.57$, statistically significant at $p<0.001$ ). In general, higher service levels generate higher BVK; however, some other patterns are evident in the data. BRT routes cluster at lower BVK (below 2.0) and service level below 50,000 p.a., while LRT/SC are all higher than this (above 2.0/50,000 p.a.). European LRT has 
the highest BVK values at modest service levels, whereas American LRT ridership lies within the 2.0 to $8.0 \mathrm{BVK}$ range but with considerably higher service levels (mostly above the 100,000 vehicle trips p.a. range).

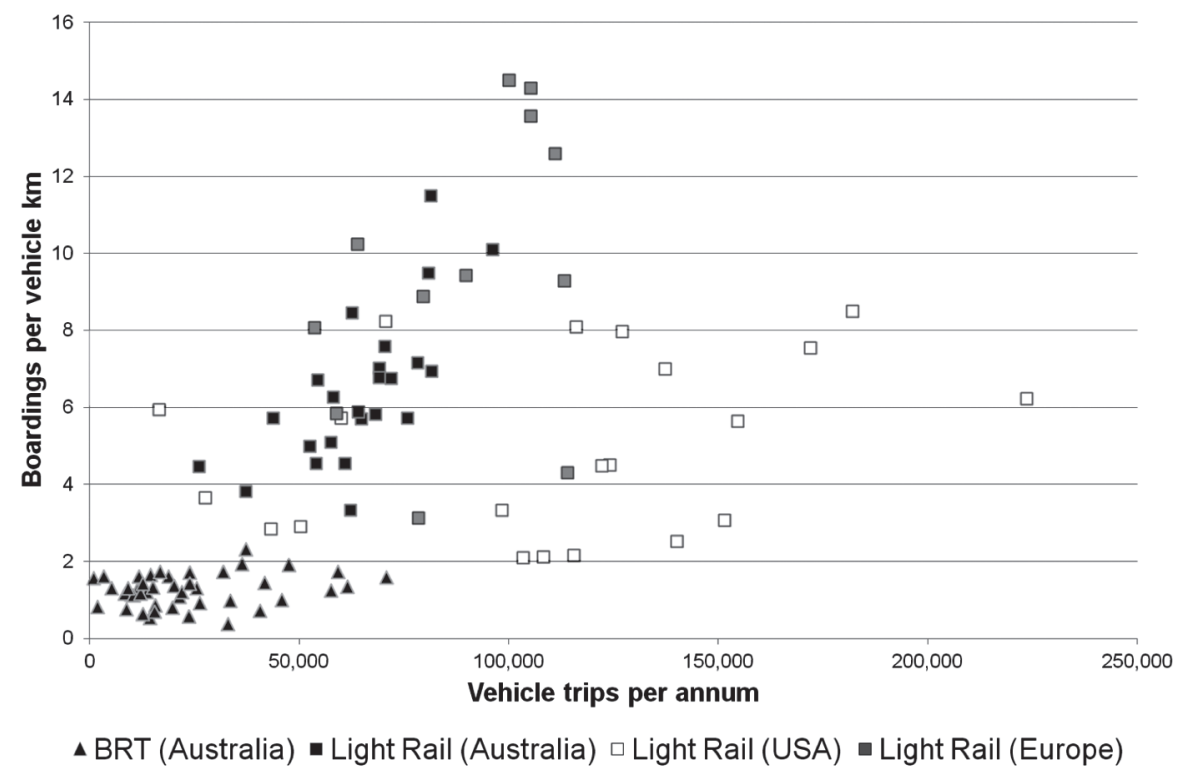

Figure 1. Boardings per vehicle $\mathrm{km}$ by vehicle trips per annum

\section{Regression Analysis}

Step-wise regression resulted in a statistically significant model, adjusted $\mathrm{R}^{2}=0.82$, $F(7,93)=67.0, p<0.0001$, with seven explanatory variables: Europe, employment density, average speed, integrated ticketing, vehicle capacity, vehicle trips per annum, and stop spacing. An analysis of possible influential cases was conducted to determine whether any of the data points were significant outliers or had an unduly large influence on the model results. Two Toronto routes (509/510 and 512) were found to have an unduly large influence, and so did the Charlotte Lynx LRT system. The Mahalanobis distances were over 20 and leverage values were over 3 times the average, indicating unambiguously that these three data points were having an unusually large influence on the model.

The model was re-run without these three data points, and this time the model changed slightly with their removal; stop spacing was no longer significant. The results of the model without these three data points are shown in Table 5. The 
model has the same explanatory power, adjusted $\mathrm{R}^{2}=0.83, F(6,91)=78.6, p<$ 0.0001. Collinearity was not evident.

Table 5. Boardings per Vehicle Kilometer Multiple Regression Model

\begin{tabular}{|c|c|c|c|c|}
\hline \multicolumn{5}{|c|}{$\mathrm{R}^{2}$ (adjusted $)=0.83 F(6,91)=78.6, p<0.0001$} \\
\hline Variable & B & SE B & Beta $(\beta)$ & t-value \\
\hline Constant & 2.13 & 0.82 & & \\
\hline Europe & 5.55 & 0.60 & 0.52 & $9.31^{\mathrm{a}}$ \\
\hline Average speed & -0.17 & 0.03 & -0.32 & $-6.70^{\mathrm{a}}$ \\
\hline Vehicle capacity & 0.78 & 0.19 & 0.28 & $4.10^{\mathrm{a}}$ \\
\hline Employment density $(1,000 s)^{c}$ & 0.30 & 0.06 & 0.26 & $5.19^{\mathrm{a}}$ \\
\hline Vehicle trips per annum $(1,000 \mathrm{~s})^{\mathrm{c}}$ & 0.02 & 0.006 & 0.20 & $3.16^{\mathrm{b}}$ \\
\hline Integrated ticketing & 1.53 & 0.39 & 0.18 & $3.91^{\mathrm{a}}$ \\
\hline
\end{tabular}

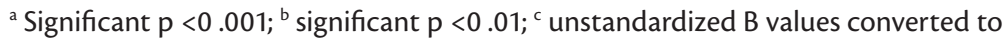
1,000 s for ease of interpretation; this does not change the standardized Beta values $(\beta)$.

The six significant predictors were (in order of influence): being in Europe, average running speed, vehicle capacity, ${ }^{2}$ employment density, vehicle trips per annum, and integrated ticketing. Being in Europe $(\beta=.58)$ had a large influence on BVK; if everything else was equal, routes in Europe had 6.1 more boardings per vehicle $\mathrm{km}$ than routes elsewhere.

\section{Discussion and Conclusion}

Being in Europe was the most influential ridership driver identified in the analysis $(\beta=0.52)$, suggesting that European LRT achieves a bonus ridership factor of some considerable size. The cause is intriguing since the analysis has already allowed for differences in car ownership, residential and employment density, and other system design features known to be different in Europe. Pedestrianization is high in Europe and has been linked to higher LRT usage in other studies (Hass-Klau and Crampton 2002). Public transport mode share is also considerably higher in Europe with 12/15 percent in France/UK compared to 5 percent in Australia, 3 percent in the U.S. and 8 percent in Canada (Kenworthy and Laube 2001). Higher mode share, in turn, may be a proxy for a greater "network effect." European transit networks have greater scale than the others examined, which is partly related to mode share.

Employment density is also significant with an effect size of $\beta=0.26$. This is consistent with previous research (Kain and Liu 1999) and suggests that penetrating 
high trip attractors such as CBD employment sites is important for both BRT and LRT/SC ridership.

The results collectively support the case for high service levels as a driver of ridership regardless of the transit mode (LRT, SC or BRT) adopted (effect size of $\beta=$ 0.20), which supports much past research (e.g., Currie and Wallis 2008; Hensher and Golob 2008; Kain and Liu 1999). This is particularly interesting in this context where boardings per vehicle kilometer was used as the outcome variable, as BVK controls for service level. This suggests that routes with higher service levels are more efficient and attract more ridership than low-service routes, all other things being equal. Note that BVK does not distinguish between service frequency and service span; for example, extending transit service hours can provide higher-thanexpected ridership growth (Currie and Loader 2009).

Integrated ticketing was also shown to be important but had a relatively modest effect size of $\beta=0.18$. This is consistent with much of previous research, demonstrating the need to plan networks (and associated fares/ticketing) on a networkwide basis to improve the passenger transfer performance of major corridor modes like BRT/LRT and SC.

Interestingly mode (BRT/LRT/SC) is NOT significant in this model. Instead, the effect of vehicle capacity $(\beta=0.28)$ is a significant predictor of BVK. Of course, it is important to consider that BRT systems are often (but not always) constrained by smaller vehicles, and indeed some of the more successful BRT systems are facing great challenges in expanding their capacity (e.g., Jaiswal et al. 2007). In addition, modal decisions need to consider the relative costs of implementing modes and other factors such as the impact on land use. The costs of a BRT system vary between US\$5 million to more than US\$50 million per kilometer (Hensher and Golob 2008), but, in most cases, are far lower than the cost of fixed rail systems.

Negative speed impacts on ridership $(\beta=-0.32)$ imply that slower routes achieve higher ridership. Negative outcomes of this kind are common in analysis of this kind (Hass-Klau and Crampton 2002; Crampton 2002) and can be caused by longer dwell times due to higher ridership and operations in high-density congested areas, which slow operations. This finding does not support a policy for slowing LRT/SC/ BRT systems down but rather supports the principle of penetration of high-density trip attractors in route design and transit-oriented development around stops and stations. 
There are clearly many opportunities for research of this kind to be expanded. Analyzing only Australian BRT systems is a major limitation that would be overcome by exploring North American and European BRT routes. Inclusion of more European as well as South American and Asian BRT/LRT systems would broaden the analysis. A within-region analysis may give specific insight within a comparable geographic context if enough BRT/ LRT routes were available for analysis. Fares, vehicle capacity, pedestrianization, and city-wide transit mode share would be useful additions as explanatory variables if available. It would be particularly useful to explore the causes of the "European" ridership boost factor through the inclusion of a wider set of explanatory variables.

Overall, the results suggest that transit mode does have a significant ridership impact, at least in regards to boardings per vehicle kilometre. The cost effectiveness of this when constructing and operating BRT and LRT/SC systems is the subject of other research. Regardless of transit mode, service levels, employment density, and integrated ticketing are also influential factors in achieving high ridership transit systems.

\section{Endnotes}

${ }^{1}$ As noted by a reviewer, BVK somewhat favors routes with higher-capacity vehicles. For example, a tram carrying 50 people every 10 minutes would have a higher BVK than 2 buses arriving every 5 minutes carrying 25 people per bus. The implications of this point are discussed.

${ }^{2}$ Early versions of this analysis did not include vehicle capacity, and this variable was replaced by transit mode (BRT lower than other modes). When capacity is taken into account, mode is no longer a significant predictor. 


\section{Appendix A: Data Sources}

\begin{tabular}{|c|c|c|c|c|}
\hline \multirow{2}{*}{$\begin{array}{l}\text { Variable/ } \\
\text { Measure }\end{array}$} & \multicolumn{4}{|c|}{ Method and Source } \\
\hline & $\begin{array}{l}\text { Australia } \\
\text { (BRT) }\end{array}$ & $\begin{array}{l}\text { Australia } \\
\text { (LRT/SC) }\end{array}$ & $\begin{array}{l}\text { North } \\
\text { America }\end{array}$ & Europe \\
\hline \multicolumn{5}{|l|}{ Boardings per Year } \\
\hline $\begin{array}{l}\text { Used to calculate } \\
\text { boardings/ route and } \\
\text { vehicle } \mathrm{km}\end{array}$ & $\begin{array}{l}2008 \text { data } \\
\text { provided by } \\
\text { operators }\end{array}$ & $\begin{array}{l}2007 \text { data } \\
\text { provided by } \\
\text { operators }\end{array}$ & $\begin{array}{l}\text { Toronto - } \\
\text { TTC } \\
\text { US - FTIS }\end{array}$ & $\begin{array}{l}\text { Based on SYPTE } 3 \\
\text { and website data }\end{array}$ \\
\hline \multicolumn{5}{|l|}{ Vehicle Kilometers } \\
\hline $\begin{array}{l}\text { Used to calculate } \\
\text { boardings / vehicle } \\
\text { km }\end{array}$ & $\begin{array}{l}2008 \text { data } \\
\text { provided by } \\
\text { operators } \\
\text { except Sydney } \\
\text { T80 - based on } \\
\text { timetables }\end{array}$ & $\begin{array}{l}\text { Melbourne } \\
\text { provided by } \\
\text { operator; oth- } \\
\text { ers estimated } \\
\text { from published } \\
\text { timetables }\end{array}$ & $\begin{array}{l}\text { As above for } \\
\text { Boardings p.a. }\end{array}$ & $\begin{array}{l}\text { Based on SYPTE } 3 \\
\text { and website data }\end{array}$ \\
\hline \multicolumn{5}{|l|}{ Service Level } \\
\hline $\begin{array}{l}\text { Vehicle trips per } \\
\text { annum }\end{array}$ & $\begin{array}{l}\text { Provided by } \\
\text { operators }\end{array}$ & $\begin{array}{l}\text { Based on an } \\
\text { analysis of } \\
\text { published } \\
\text { timetables for } \\
2007\end{array}$ & $\begin{array}{l}\text { Toronto - } \\
\text { TTC }^{1} \text { US - } \\
\text { FTIS }^{2}\end{array}$ & $\begin{array}{l}\text { Based on SYPTE } 3 \\
\text { and website data }\end{array}$ \\
\hline \multicolumn{5}{|l|}{ Vehicle Capacity } \\
\hline $\begin{array}{l}\text { Five categories based } \\
\text { on sitting and stand- } \\
\text { ing room }\end{array}$ & $\begin{array}{l}\text { Provided by } \\
\text { operators }\end{array}$ & $\begin{array}{l}\text { Provided by } \\
\text { operators }\end{array}$ & $\begin{array}{l}\text { Various Inter- } \\
\text { net sources }\end{array}$ & $\begin{array}{l}\text { Various Internet } \\
\text { sources }\end{array}$ \\
\hline \multicolumn{5}{|l|}{ Residential Density } \\
\hline $\begin{array}{l}\text { Residents per square } \\
\text { metre }\end{array}$ & $\mathrm{ABS}^{5}$ & $\mathrm{ABS}^{5}$ & $\begin{array}{l}\text { Toronto } \\
- \text { SC }^{6}, \text { US - } \\
\text { census }\end{array}$ & $\begin{array}{l}\text { Dublin: } \text { CSO }^{8} \text { UK: } \\
\text { census } \\
\text { Others: based on } \\
\text { SYPTE }^{3} \\
\text { Rouen - estimated } \\
\text { from Wikipedia }\end{array}$ \\
\hline \multicolumn{5}{|l|}{ Employment Density } \\
\hline $\begin{array}{l}\text { Jobs per square } \\
\text { metre }\end{array}$ & $\mathrm{ABS}^{5}$ & $\mathrm{ABS}^{5}$ & $\begin{array}{l}\text { Toronto - } \\
\text { SC }^{6} \\
\text { US - FTIS }\end{array}$ & $\begin{array}{l}\text { Dublin: } \mathrm{CSO}^{8} \text { UK: } \\
\text { census }^{9} \\
\text { Others: based on } \\
\text { SYPTE }^{3} \\
\text { Selected European } \\
\text { centers using data } \\
\text { from INSEE }\end{array}$ \\
\hline
\end{tabular}




\begin{tabular}{|c|c|c|c|c|}
\hline \multicolumn{5}{|l|}{ Car Ownership } \\
\hline $\begin{array}{l}\text { Cars per } 1,000 \\
\text { residents }\end{array}$ & $\mathrm{ABS}^{5}$ & $\mathrm{ABS}^{5}$ & $\begin{array}{l}\text { Toronto - TT } \\
\text { Survey }^{11} \\
\text { US - census }\end{array}$ & $\begin{array}{l}\text { Dublin: } \text { CSO }^{8} \\
\text { UK: census } \\
\text { France- CERTU } \\
\end{array}$ \\
\hline \multicolumn{5}{|l|}{ Route Length } \\
\hline $\begin{array}{l}\text { Used to calculate } \\
\text { service level, speed, } \\
\text { stop spacing \& ROW }\end{array}$ & $\begin{array}{l}\text { Calculated } \\
\text { using Google } \\
\text { Earth }\end{array}$ & $\begin{array}{l}\text { Melbourne } \\
\text { provided by op- } \\
\text { erator; others } \\
\text { Google Earth }\end{array}$ & $\begin{array}{l}\text { Toronto - } \\
\text { TTC data } \\
\text { Google Earth }\end{array}$ & $\begin{array}{l}\text { Mix of website data } \\
\text { and Google Earth } \\
\text { Route Inspection } \\
\text { UK/Dublin - web- } \\
\text { site data }{ }^{4}\end{array}$ \\
\hline \multicolumn{5}{|l|}{ Speed } \\
\hline $\begin{array}{l}\text { Average travel time } \\
\text { divided by route } \\
\text { length (kph) }\end{array}$ & $\begin{array}{l}\text { Published } \\
\text { timetables }\end{array}$ & $\begin{array}{l}\text { As above for } \\
\text { service level }\end{array}$ & $\begin{array}{l}\text { As above for } \\
\text { service level }\end{array}$ & $\begin{array}{l}\text { As above for service } \\
\text { level }\end{array}$ \\
\hline \multicolumn{5}{|l|}{ Stop Spacing } \\
\hline $\begin{array}{l}\text { Route length divided } \\
\text { by number of stops } \\
\text { minus } 1\end{array}$ & $\begin{array}{l}\text { Published } \\
\text { timetables }\end{array}$ & $\begin{array}{l}\text { As above for } \\
\text { service level }\end{array}$ & $\begin{array}{l}\text { As above for } \\
\text { service level }\end{array}$ & $\begin{array}{l}\text { As above for service } \\
\text { level }\end{array}$ \\
\hline \multicolumn{5}{|c|}{ Share Segregated Right-of-Way } \\
\hline $\begin{array}{l}\text { Proportion of track } \\
\text { out of mixed traffic }\end{array}$ & $\begin{array}{l}\text { Calculated } \\
\text { using Google } \\
\text { Earth }\end{array}$ & $\begin{array}{l}\text { Data provided } \\
\text { by VicRoads } \\
\text { and an analysis } \\
\text { of Google Maps }\end{array}$ & $\begin{array}{l}\text { Toronto: } \\
\text { based } \\
\text { on route } \\
\text { inspection; } \\
\text { others : visual } \\
\text { inspection of } \\
\text { Google Maps }\end{array}$ & $\begin{array}{l}\text { Visual inspection of } \\
\text { Google Maps Dub- } \\
\text { lin: Data provided } \\
\text { by RPA UK systems: } \\
\text { website data }\end{array}$ \\
\hline \multicolumn{5}{|l|}{ Share Accessible Stops } \\
\hline $\begin{array}{l}\text { Proportion of stops } \\
\text { that are wheelchair } \\
\text { accessible }\end{array}$ & $\begin{array}{l}\text { Published } \\
\text { timetables and } \\
\text { operators }\end{array}$ & $\begin{array}{l}\text { As above for } \\
\text { service level }\end{array}$ & $\begin{array}{l}\text { As above for } \\
\text { service level }\end{array}$ & $\begin{array}{l}\text { As above for service } \\
\text { level }\end{array}$ \\
\hline \multicolumn{5}{|l|}{ Integrated Fares } \\
\hline $\begin{array}{l}\text { No fare on mode } \\
\text { transfer }\end{array}$ & $\begin{array}{l}\text { Operator } \\
\text { website }\end{array}$ & $\begin{array}{l}\text { Operator } \\
\text { website }\end{array}$ & $\begin{array}{l}\text { Operator } \\
\text { website }\end{array}$ & Operator website \\
\hline
\end{tabular}

${ }^{1}$ Toronto Transit Commission 2008 data (www.ttc.ca) (last accessed Nov 2009).

22006 data from Florida Transit Information System, http://www.ftis.org/ (last accessed Nov 2009).

${ }^{3}$ Study of European Light Rail Performance for South Yorkshire Passenger Transport Executive undertaken by Egis Semaly Ltd and Faber Maunsell (2003). Data are thought to be related to calendar year 2003.

${ }^{4}$ UK/Dublin website data at www.tramlink.co.uk, www.centro.org.uk, www.railway-technology. com, www.supertram.com http://www.rpa.ie/en/Pages/default.aspx (last accessed Nov 2009). 
${ }^{5}$ GIS Analysis of 2006 census (Australian Bureau of Statistics 2006).

${ }^{6}$ Based on 2006 data and GIS analysis (Statistics Canada 2007).

${ }^{7}$ Major statistical area, 2000 (U. S. Census Bureau 2000), http://www.census.gov/ (last accessed Nov 2009).

${ }^{8} \mathrm{GIS}$ analysis of Central Statistics Office, Ireland, Census for 2006 at http://www.cso.ie/ (last accessed Nov 2009).

${ }^{9} \mathrm{GIS}$ analysis of UK Census data for 2001, https://www.census.ac.uk/Default.aspx (last accessed Nov 2009).

${ }^{10}$ INSEE - National Institute of Statistics and Economic Studies - France, http://www.insee.fr/en/ default.asp (last accessed Nov 2009).

${ }^{11}$ Transport Tomorrow Survey (University of Toronto 2006).

${ }^{12}$ Center for Studies on Networks, Transport, Urban Planning and Public Works, France, http:// www.certu.fr/spip.php?page $=$ sommaire\&lang $=$ en (last accessed Nov 2009).

\section{References}

Australian Bureau of Statistics. 2006. Census of population and housing.

Babalik-Sutcliffe, E. 2002. Urban rail systems: analysis of the factors behind success. Transport Reviews 22: 415-417.

Barnett, V., and T. Lewis. 1978. Outliers in Statistical Data. New York: Wiley.

Crampton, G. 2002. International comparison of urban light rail systems: The role of integrated ticketing, pedestrianisation and population density. In European Regional Science Association (ERSA) 2002. Dortmund, Germany.

Currie, G. 2005. The demand performance of Bus Rapid Transit. Journal of Public Transportation 8(1): 41-55.

Currie, G., and C. Loader. 2009. High ridership growth from extended transit service hours - An exploration of causes. In Transportation Research Board Meeting, Washington, DC, January 2009.

Currie, G., and I. Wallis. 2008. Effective ways to grow urban bus markets - A synthesis of evidence. Journal of Transport Geography 16: 419-429.

Currie, Graham, Aoife Ahern, and Alexa Delbosc. 2011. Exploring the drivers of light rail ridership: An empirical route level analysis of selected Australian, North American and European systems. Transportation 38(3): 545-560.

Currie, Graham, and Alexa Delbosc. 2010. Bus rapid transit in Australasia: An update on progress. Built Environment 36(3): 305-320. 
Exploring Comparative Ridership Drivers of Bus Rapid Transit and Light Rail Transit Routes

Currie, Graham, and Alexa Delbosc. 2011. Understanding bus rapid transit systems ridership drivers - An empirical study of Australian BRT systems. Transport Policy 18(5): 755-764.

Denant Boemont, L., and G. Mills. 1999. Urban light rail: Intermodal competition or coordination? Transport Reviews 19: 241-253.

Egis Semaly Ltd. and Faber Maunsell. 2003. Comparative performance data from French tramsway systems - Final report for South Yorkshire passenger transport executive.

FitzRoy, F., and I. Smith. 1998. Public transport demand in Freiburg: Why did demand double in a decade? Transport Policy 5: 163-173.

Hass-Klau, C., and G. Crampton. 2002. Future of Urban Transport: Learning from Success and Weakness_Light Rail. Edited by E. A. T. Planning and B. U. G. Wuppertal. Brighton, UK: Environment and Transport Planning.

Hensher, D. A. , and T. F. Golob. 2008. Bus rapid transit systems - A comparative assessment. Transportation 35(4): 501-518.

Jaiswal, S., J. Bunker, and L. Ferreira. 2007. Operating characteristics and performance of a busway transit station. In 30th Australasian Transport Research Forum. Melbourne, Australia.

Johnson, A. 2003. Bus transit and land use: Illuminating the interaction. Journal of Public Transportation 6(4): 21-39.

Kain, J., and Z. Liu. 1999. Secrets of success: The large increases in transit ridership achieved by Houston and San Diego transit providers. Transportation Research A 33: 601-624.

Kain, M., A. Barranda, and C. Upchurch. 2004. Factors influencing light-rail station boardings in the United States. Transportation Research A 38: 223-247.

Kenworthy, J., and F. Laube. 2001. The Millennium Cities Database for Sustainable Transport. Brussels: International Union of Public Transport (UITP).

Knowles, R. 2007. What future for light rail in the UK after Ten Year Transport Plan Targets are scrapped? Transport Policy 14: 81-93.

Levinson, H., S. Zimmerman, J. Clinger, S. Rutherford, R. L. Smith, J. Cracknell, and R. Soberman. 2003. Bus Rapid Transit. TCRP Report 90, edited by T. C. R. Program: Transportation Research Board, Washington, DC. 
Mackett, R., and E. Babalik-Sutcliffe. 2003. New urban rail systems: A policy based technique to make them more successful. Journal of Transport Geography 11: 151-164.

Myers, R. 1990. Classical and Modern Regression with Applications (2nd Ed.). Boston, MA: Duxbury.

Nielsen, G., J. D. Nelson, C. Mulley, G. Tenger, G. Lind, and T. Lange. 2005. Public transport-Planning the networks. Vol. Guide No. 2, Hi Trans Best Practice Guide.

Seskin, S., and R. Cervero. 1996. Transit and Urban Form. Washington, DC: Federal Transit Administration.

Statistics Canada. 2007. Ontario (table). 2006 Community Profiles. 2006 Census.

Stevens, J. P. 2002. Applied Multivariate Statistics for the Social Sciences (4th ed.). Hillsdale, NJ: Erlbaum.

Stopher, P. 1992. Development of a route level patronage forecasting method. Transportation 19: 201-220.

U. S. Census Bureau. 2000. Profile of selected social characteristics.

U.S. General Accounting Office. 2001. Bus Rapid Transit shows promise. Washington DC.

UK Commission for Integrated Transport. 2005. Affordable Mass Transit. UK: UK Commission for Integrated Transport.

University of Toronto. 2006. Transportation Tomorrow Survey. Toronto, Canada: Data Management Group, University of Toronto.

\section{Acknowledgments}

The authors would like to thank Aoife Ahern for assistance in collating some of the LRT data in this study, the Urban Institute in University College Dublin for part-funding Ms. Delbosc's sabbatical to Monash University, and Susanna Schmidt of the Urban Institute Dublin for help with processing European elements of the LRT data. In addition, Karen Woo of the University of Toronto assisted by collecting some of the North American LRT data while on a visit to Monash from the University of Toronto. We would also like to thank Patrick Bonnel, Professor of Transport Economics, ENTPE France, for advice on sources for collecting data from 
France, the Victoria Department of Transport for sponsorship of the BRT elements of the research, and the staff of the transit authorities in each state of Australia who assisted in collating the BRT data input to this research. We would also like to thank Ian Wallis for ideas and suggestions on the BRT work. Any omissions or errors are the responsibility of the authors.

\section{About the Authors}

Graham CURRIE (graham.currie@monash.edu) is Professor of Public Transport at the Institute of Transport Studies, Monash University, and has more than 30 years' experience in planning and researching transit system planning and development worldwide. He is a member of TRB Bus Transit Systems, Light Rail Transit Systems, and Public Transport Planning and Development Committee and directs the World Transit Research Clearinghouse (www.worldtransitresearch.info). He has published some 200 research papers on transit in leading world research journals and conferences.

Alexa Delbosc (alexa.delbosc@monash.edu) is a research fellow in the Institute of Transport Studies, Monash University. Her research interests include public transport ridership, traveler behavior, the social implications of public transport, and transport disadvantage. Her background is in social research from her studies in social psychology at Harvard University. Her work at Harvard culminated in a collaborative project on the egocentric estimation of God's beliefs, which was published in the Proceedings of the National Academy of Sciences. 